\title{
Arbor
}

\section{Una Perspectiva sobre la Situación Actual de la Virología}

\section{Esteban Domingo y Margarita Salas}

Arbor CLXVIII, 662 (Febrero 2001), 191-208 pp.

La Virología se ha desarrollado durante la última parte del siglo XX en paralelo con las nuevas técnicas de análisis y manipulación genética y con el auxilio de técnicas físicas e informáticas. En España se han formado núcleos activos tanto en genética viral como en virus patógenos de animales y plantas. Contrariamente a predicciones de hace tan solo tres décadas, las enfermedades víricas siguen siendo un importante problema en medicina, veterinaria y agricultura. Un gran número de enfermedades víricas emergentes constituyen un importante desafio para el siglo XXI.

\section{Nacimiento y desarrollo inicial de la Virología}

La Virología, quizás con más propiedad que cualquier otra rama de las ciencias biológicas, puede considerarse enteramente un desarrollo del siglo XX. Su nacimiento se atisbó en las postrimerías del siglo XIX con observaciones germinales de Loeffler y Frosch con el agente causal de la fiebre aftosa $^{1}$ y de Beijerinck con el del mosaico del tabaco ${ }^{2}$. En ambos estudios se reconoció la naturaleza singular -incompatible con que se tratase de bacterias o de toxinas- de los agentes de dichas enfermedades.

Durante la primera década del siglo XX se identificaron numerosos virus como el virus de la fiebre amarilla por Reed y sus colaboradores, 
el virus de la peste aviar por Lode y Gruber, el de la rabia por Remlinger, Riffat-Bay y Negri, o el de la poliomielitis por Landsteiner y Popper, entre otros virus ${ }^{3}$.

Acontecimientos posteriores clave para el desarrollo de la Virología fueron la cristalización del virus del mosaico del tabaco por Stanley ${ }^{4}$ así como el reconocimiento de la presencia tanto de ácido nucleico como de proteína en este agente infeccioso ${ }^{5}$.

Los virus que infectan bacterias, denominados bacteriófagos (o abreviadamente fagos) jugaron un papel central en el desarrollo tanto de la Virología como de la Biología Molecular. Su existencia fue propuesta inicialmente por Twort en 1915 y fueron descritos con mayor detalle por d'Herèlle en $1917^{6}$. Los fagos despertaron interés como posibles agentes terapéuticos por su capacidad de lisar bacterias patógenas. Aunque nunca hallaron una aplicación terapéutica resulta curioso que a finales del siglo XX ha renacido el interés por su posible aplicación antibacteriana, animado quizás por la creciente prevalencia de bacterias patógenas resistentes a uno o múltiples antibióticos.

La contribución más fundamental de los bacteriófagos al desarrollo de la Biología Molecular surgió de los trabajos de Delbrück y sus asociados a partir de la década de los 40: el llamado grupo de los fagos («phage group») $)^{7}$. Delbrück y Luria tenían un convencimiento profundo de que los fagos permitirían comprender la naturaleza de los genes y su funcionamiento. Y más provocativo todavía, buscaban afanosamente nuevos «principios» que explicasen el comportamiento de los seres vivos y que difiriesen de los principios de la física y de la química cuya naturaleza aparecía como ya firmemente establecida.

A la caracterización del ciclo replicativo de los bacteriófagos con DNA siguió el clásico experimento de Hershey y Chase que sugirió que el material genético e infeccioso de los fagos era el ácido desoxirribonucleico (DNA) y no la proteína ${ }^{8}$. Este experimento fue casi coetáneo con la elucidación de la estructura de la doble hélice del DNA por Watson, Crick y Franklin. La conjunción de los reultados estructurales sobre el DNA con los del grupo de los fagos - con Adams, Hershey, Luria y Delbrück como protagonistas más destacados - reveló de modo casi inmediato tanto la naturaleza de los virus y de su material genético como las líneas generales que debían regir su replicación, a través de la síntesis de cadenas de DNA complementarias a las de DNA molde, siguiendo las reglas de apareamiento de bases: adenina con timina y guanina con citosina. Había nacido la biología molecular. 


\section{Los virus y su implicación en la gran revolución de la biología: la ingeniería genética}

La segunda mitad del siglo XX deparó muchas sorpresas en el desarrollo de la virología y una gran revolución que afectó, y sigue afectando, a todo el ámbito de la Biología: la capacidad de aislar y modificar de modo controlado el material genético de los organismos vivos. Pero dentro de la Virología cabe destacar nuevas observaciones. Se demostró que la infectividad del virus del mosaico del tabaco también residía en su ácido nucleico que era ácido ribonucleico (RNA) y no DNA. Además se aislaron numerosos virus cuyo material genético era RNA, notablemente varios fagos ${ }^{9}$ que diferían en sus propiedades replicativas de los estudiados por Delbrück y sus asociados. En la década de los 60 Spiegelman y su grupo desarrollaron el primer sistema de replicación en el tubo de ensayo, empleando uno de los fagos con RNA que acababan de ser descubiertos: el bacteriófago Qß. El RNA se copiaba mediante una replicasa viral obtenida a partir de extractos de Escherichia coli infectada con el fago, un factor proteico de la misma bacteria y ribonucleósido trifosfatos como sustratos monoméricos ${ }^{10}$. Ello implicaba que el material genético podía sintetizarse a partir de unos pocos componentes purificados, fuera del contexto de la célula viva. En esta época Weissmann, trabajando en el grupo de Ochoa en Nueva York, demostró que la replicación del RNA del fago $\mathrm{Q} ß$ también tenía lugar, como en el caso del DNA, a través de la síntesis de una cadena de RNA de polaridad contraria a la del RNA presente en el virus ${ }^{11}$. La replicación seguía las reglas de apareamiento de bases ya establecidas para el DNA, ocupando el uracilo el lugar de la timina. En el grupo de Ochoa de Nueva York se realizaban en esta época experimentos muy fundamentales en Biología Molecular encaminados a elucidar el mecanismo de lectura del material genético para la biosíntesis de proteínas. Eladio Viñuela y uno de nosotros (M.S.) participaron activamente en estos avances ${ }^{12}$ que posteriormente permitieron iniciar uno de los núcleos de desarrollo de la Biología Molecular y de la Virología en España, en el Centro de Investigaciones Biológicas.

En Nueva York, Eladio Viñuela participó en el desarrollo de una técnica de separación de proteínas por electroforesis en medio desnaturalizante que tuvo una gran utilidad para los análisis de composición de virus y de mezclas de proteínas celulares, y que resultó uno de los trabajos más citados en la historia de la Biología ${ }^{13}$. 
El grupo iniciado en el Centro de Investigaciones Biológicas por Eladio Viñuela y M.S. utilizó como sistema modelo el bacteriófago $\varnothing 29$ que infecta Bacillus subtilis. El estudio del fago ø29 llevó a la elucidación por primera vez en España de la estructura de un virus, así como su morfogénesis, con la identificación de proteínas morfogenéticas, que intervienen en la formación del virus pero no forman parte del virus maduro. Por otra parte, se caracterizó por primera vez una proteína unida covalentemente a los extremos 5' del DNA viral, lo que ha supuesto un nuevo mecanismo de iniciación de la replicación del DNA del virus. Este tipo de proteínas unidas a ácidos nucléicos virales, implicadas en la iniciación de la replicación, se encuentran en virus de animales y de plantas de un gran interés sanitario y económico, como, por ejemplo, adenovirus, el virus de la poliomelitis, el de la fiebre aftosa, etc. ${ }^{14,15}$.

El sistema de replicación del RNA de $\mathrm{Q} ß$ in vitro, desarrollado por los grupos de Spiegelman y Weissmann, sigue siendo uno de los sistemas más eficaces para la replicación de un RNA viral y permitió realizar una década más tarde los primeros experimentos de mutagénesis dirigida ${ }^{16}$ y revelar una alta tasa de error durante la replicación del fago $\mathrm{Q} \beta^{17}$. Las altas tasas de error calculadas por primera vez por Weissmann y sus asociados son una característica compartida por otros virus RNA de animales y plantas y subyacen al poder de adaptación y de persistencia de muchos virus patógenos. El problema de la variabilidad genética de los virus RNA sigue actualmente investigándose en el Centro de Biología Molecular «Severo Ochoa» por uno de nosotros (E.D.), como continuación de un grupo de trabajo que se inició en colaboración con Juan Ortín en 1978.

Uno de los mayores logros de la Virología del siglo XX fue la determinación por Fiers y sus colaboradores de la secuencia de nucleótidos del genoma completo del fago MS2, emparentado con el fago Qß. Este logro ${ }^{18}$ representó la primera estructura completa de un genoma dotado de capacidad replicativa, una de las propiedades fundamentales que definen la vida. El mecanismo de replicación de los fagos RNA resultó un modelo adecuado para otros virus RNA de animales y plantas que, aunque con diferencias en el detalle molecular, se multiplican a través de una cadena de RNA complementario a la cadena presente en las partículas virales.

No obstante, el modelo replicativo a través de moléculas de RNA de secuencia y polaridad complementarias no era universal y la excepción propició uno de los pilares en los que se asentó la gran revolución de la Biología. 
Una perspectiva sobre la situación actual de la Virología

\section{Retrotranscriptasa o el fin del dogma de la biología molecular}

El desarrollo de la Biología Molecular hasta 1970 había conducido a una generalización acerca del flujo de la información genética en los organismos vivos que puede representarse como:

$$
\text { DiNA } \rightarrow \text { RNA } \rightarrow \quad \text { Proteína }
$$

en el que la flecha en forma de círculo representa la replicación del material genético y las flechas horizontales el flujo irreversible de información mediante dos procesos de expresión genética: la transcripción o copia de DNA en RNA y la traducción o copia del mensaje genético en forma de cadena de aminoácidos. La transcripción originaba las distintas formas conocidas de RNA: ribosomal, mensajero, de transferencia y varios RNAs de bajo peso molecular. La traducción era el proceso clave para generar tanto proteínas estructurales como enzimáticas, sometidas frecuentemente a modificaciones post-traduccionales (procesamiento proteolítico, fosforilación, glicosilación, acetilación, etc.) y cuyo estudio constituía la materia central de la Bioquímica. El flujo de información genética DNA $\rightarrow$ RNA $\rightarrow$ Proteína era conocido como el «dogma de la Biología Molecular», tal era la convicción sobre su veracidad general.

El dogma se quebró a comienzos de la década de los 70 con el descubrimiento por Baltimore y Temin de una enzima presente en un grupo de virus animales, que actualmente reciben el nombre de retrovirus, y que era capaz de copiar RNA en DNA: la transcriptasa en reverso o retrotranscriptasa ${ }^{19}$. El esquema del flujo de información genética debía reescribirse:

$$
\text { DiNA } \quad \leftarrow \text { RNA } \rightarrow \text { Proteína }
$$

Los retrovirus contienen esta enzima en sus partículas porque su ciclo replicativo incluye una etapa de DNA que se integra en el DNA celular. La síntesis de RNA y proteínas víricas ocurre a partir del DNA integrado, denominado DNA proviral. La retrotranscriptasa carece de especificidad de molde y a partir de un iniciador adecuado permite copiar cualquier RNA en DNA. Ello incluye a RNAs mensajeros celulares codificantes de proteínas con importantes propiedades biológicas (como enzimas, hormonas, citoquinas, factores de crecimiento, etc.) cuyo men- 
saje queda registrado en forma de DNA. El DNA puede ser transferido a vectores plasmídicos o víricos para su amplificación y manipulación. Ello fue posible por el desarrollo paralelo de la enzimología del DNA, que permitió disponer de una batería de enzimas capaces de alterar DNA de un modo que no resultaba practicable con $\mathrm{RNA}^{20}$.

\section{El papel de los virus en el desarrollo de la ingeniería genética}

Varias actividades enzimáticas que permitían la síntesis y modificación de moléculas DNA fueron caracterizadas a nivel funcional y estructural durante la segunda mitad del siglo XX: DNA polimerasas, DNA ligasas, polinucleótido quinasas, exonucleasas y endonucleasas de restricción, entre otras. Precisamente las endonucleasas de restricción de tipo II, que reconocen y cortan el DNA en secuencias específicas, permitieron obtener fragmentos definidos que se conocen como fragmentos de restricción. Las DNA ligasas hicieron posible la unión de fragmentos de DNA de orígenes distintos para formar DNA quiméricos, el punto inicial de la manipulación tanto de DNAs víricos, como bacterianos y celulares. Cabe destacar que en el grupo de Eladio Viñuela y uno de nosotros (M.S.) se utilizaron por primera vez en España las endonucleasas de restricción, concretamente la EcoRI, con la que Marta $R$. Inciarte y José $M^{\mathrm{a}}$ Lázaro construyeron el primer mapa físico del DNA de $\varnothing 29$, y su correlación con el mapa genético ${ }^{21}$.

Los virus tuvieron una presencia importante en el desarrollo de la ingeniería genética y a su vez ésta aceleró muy notablemente el desarrollo de la Virología. Los primeros DNA quiméricos construidos por Berg ${ }^{22}$ y sus asociados contenían fragmentos de DNA de un virus animal, el SV40 - un papovavirus de ratón-y de un virus bacteriano -el bacteriófago $\lambda$ - Ello permitía a la quimera su replicación tanto en células animales como bacterianas. El empleo de vectores bacterianos, tanto plasmídicos como virales, para el clonaje y expresión en grandes cantidades de proteínas de interés, constituye una de las principales aplicaciones de la ingeniería genética y el origen de una nueva rama de la biología aplicada: la biotecnología.

El empleo de la retrotranscriptasa de retrovirus y la capacidad de cortar y religar DNA no solo constituye una herramienta muy importante para investigaciones en Biología Molecular y Celular sino que ha hallado una amplísima aplicación en la industria farmacéutica. RNAs mensajeros que codifican productos de interés médico, veterinario o agrícola (como son hormonas, citoquinas, factores de resistencia a 
infecciones, etc.) pudieron ser copiados en DNA, éste transferido a vectores para su amplificación y expresión en sistemas eucarióticos o procarióticos, y el producto de expresión purificado y ensayado para una posible comercialización.

A este desarrollo contribuyeron de modo definitivo las técnicas de secuenciación rápida de ácidos nucleicos que alteraron los diseños experimentales de la genética clásica.

\section{Secuenciación de nucleótidos y genética inversa: alterar antes de ensayar}

Durante la década de los 70 se pusieron a punto dos métodos de secuenciación de ácidos nucleicos que incrementaban varios ordenes de magnitud la rapidez de determinación de secuencias por los procedimientos clásicos. Se trata del método de modificación química de Maxam y Gilbert y el de síntesis enzimática y terminación de cadenas de Sanger ${ }^{23}$. El método enzimático es el que finalmente se ha impuesto y adaptado a tecnología informatizada de secuenciación automática. Al desarrollo de esta metodología contribuyó decisivamente poder disponer de fragmentos de restricción específicos y puros obtenidos a partir de DNAs plasmídicos y virales de baja complejidad.

Las primeras secuencias de nucleótidos realizadas en España, las de los extremos del DNA del fago $\varnothing 29$, fueron obtenidas por Cristina Escarmís, trabajando con M.S. ${ }^{24}$.

En España todos los núcleos importantes de Virología bacteriana, animal y de plantas han adaptado las técnicas de DNA recombinante y secuenciación de DNA como rutina de laboratorio para abordar problemas de índole básica o aplicada. En el capítulo de secuenciación de genomas víricos destaca la determinación de la secuencia completa del genoma del virus de la peste porcina africana por Eladio Viñuela y su equipo ${ }^{25}$. La peste porcina africana representó durante mucho tiempo un importante problema económico para España porque impedía la exportación de cabaña porcina y de sus productos derivados. Deseamos destacar la contribución del grupo de Eladio Viñuela al desarrollo de la genética e inmunología del virus, lo que propició que sea considerado el único miembro de una nueva familia de virus DNA altamente complejos $^{25}$. Los trabajos del grupo de Eladio Viñuela, junto con otros de índole más práctica en el Instituto Nacional de Investigaciones Agrarias, con la participación del grupo de José Manuel Sánchez Vizcaíno, culminaron en la erradicación de la enfermedad en España en 1995, con los consiguientes beneficios de tipo económico. 
Gracias a la secuenciación rápida de ácidos nucléicos se pudo conocer con gran precisión el mensaje genético en virus, bacterias y células eucarióticas, abriendo el camino a análisis estructurales y funcionales más rigurosos. Asimismo, el creciente número de secuencias propició el desarrollo de la biología evolutiva mediante comparaciones de genes con función parecida presentes en distintos tipos de virus, microorganismos o células eucarióticas. Bases de datos de secuencias, asequibles a todos los investigadores mediante procedimientos electrónicos, han facilitado grandemente las tareas de la Virología comparativa y evolutiva.

La conjunción de técnicas de recombinación de DNA in vitro ${ }^{20-22}$ con las de secuenciación de nucleótidos ${ }^{23}$ permitió también obtener genes con modificaciones de secuencia específicas y preseleccionadas. Tales diseños experimentales se conocen con el nombre de técnicas de mutagénesis dirigida y permiten ensayar las consecuencias funcionales de alteraciones específicas en zonas reguladoras o codificantes ${ }^{16,26}$. En el caso de virus, copias en DNA de genomas enteros, pueden producir progenie infecciosa al ser introducidos los DNAs o sus productos de transcripción en células susceptibles ${ }^{27}$. Por tanto, genes virales alterados pueden ser introducidos en clones infecciosos para analizar el efecto de las alteraciones sobre las distintas etapas del ciclo replicativo del virus.

$\mathrm{Al}$ conjunto de técnicas con las que primero se altera el material genético de modo diseñado y controlado, y posteriormente se analizan las consecuencias de la alteración, se conoce como genética inversa (o genética en reverso). Este término subraya la diferencia de diseño con respecto a la metodología de la genética clásica consistente en una mutagénesis al azar y la subsiguiente búsqueda de mutantes con un determinado comportamiento, para finalmente mapear el sitio de la lesión.

Más recientemente, la amplificación de genes mediante la reacción de la polimerasa en cadena (PCR) empleando DNA polimerasas termoestables se ha convertido en una técnica muy potente para el desarrollo de la Virología. Permite obtener cantidades analizables de DNA a partir de una sola molécula molde, lo que convierte al PCR en un método altamente sensible para el diagnóstico de virus, con la posibilidad de determinar secuencias de genomas virales a partir de cantidades mínimas provenientes de muestras biológicas ${ }^{28}$.

\section{Genes discontínuos: intrones, exones y procesamiento del RNA}

La primera evidencia de que los genes eucarióticos no eran colineares con los RNA mensajeros maduros y los productos de traducción que 
Una perspectiva sobre la situación actual de la Virología

codificaban, se obtuvo con adenovirus, un virus humano patogénico que ha jugado un papel importante en el desarrollo de la Virología. Las regiones codificantes de proteína en células eucarióticas, así como en muchos virus que las infectan, se hallan muy frecuentemente interrumpidas por zonas no codificantes denominadas intrones ${ }^{29}$. Ello implica que los productos primarios de la transcripción son RNAs que deben ser procesados para dar los RNA mensajeros funcionales, en un proceso de rotura y religamiento («splicing») sometido a múltiples mecanismos de regulación, en cuya investigación los virus siguen actualmente teniendo un papel relevante.

La complejidad de la estructura de los genes eucarióticos constituye una de las dificultades para la manipulación de organismos enteros tanto para fines terapéuticos (terapia génica) como de investigación (producción de animales transgénicos). No obstante, animales con genes específicos delecionados o silenciados («knock out») se han convertido en una herramienta importante para entender procesos de infección vírica in vivo.

\section{De genes a proteínas y a imágenes: proteómica}

Un aspecto complementario a la capacidad de identificar, aislar y modificar material genético es el del estudio estructural y funcional de proteínas. Las interacciones virus-célula y las perturbaciones celulares como resultado de las infecciones víricas ocurren en gran medida con la participación de proteínas. Actualmente se ha impuesto el término de proteómica para designar a un conjunto de técnicas cuyo objetivo es abordar la relación entre la estructura y la función de las proteínas, técnicas que son el contrapunto del campo de la genómica delineado en párrafos anteriores.

Para la Virología resultó de una gran importancia la preparación de anticuerpos monoclonales, con los que se pudieron definir epítopos individuales en las proteínas de superficie de virus patógenos ${ }^{30}$. Los anticuerpos monoclonales permitieron identificar sitios antigénicos con precisión molecular y abrieron el campo del diseño más racional de nuevas vacunas antivíricas, un área de investigación muy activa en la actualidad.

La proteómica hace hincapié en nuevos métodos para la separación de mezclas complejas de proteínas -mediante ténicas electroforéticas y cromatográficas con alto poder de resolución- así como micrométodos para determinar masas molares de fragmentos proteicos y secuencias de aminoácidos - mediante técnicas físicas como la espectrometría de masas-. 
Varios grupos españoles son muy activos en los diversos campos de la proteómica, a menudo organizados en forma de servicios técnicos adheridos a Universidades y a Centros del CSIC. Estos grupos representan un importante apoyo a la Virología.

La determinación de estructuras tridimensionales de proteínas virales $\mathrm{y}$ de virus enteros empleando métodos de difracción de rayos $\mathrm{X}$ está jugando un papel muy importante en la Virología actual. Se han cristalizado numerosos virus sin envuelta tanto de animales como de plantas, aunque todavía no ha sido posible cristalizar virus enteros con una envuelta lipídica. No obstante, la cristalización de proteínas de superficie que se insertan en envueltas lipídicas virales ha permitido la resolución a nivel atómico de dominios funcionalmente importantes como son los que interaccionan con receptores celulares o con anticuerpos que neutralizan la infectividad del virus. El ejemplo más clásico es el de la hemaglutinina del virus de la gripe humana. Actualmente, varios grupos tanto de química sintética - producción de péptidos víricos antigénicos- como de análisis estructurales, situados en Universidades y Centros del CSIC están representando un importante apoyo a proyectos de Virología en curso.

Desde su invención en la primera parte del siglo XX la microscopía electrónica ha sido una herramienta fundamental para el desarrollo de la Virología. Recientemente, métodos de reconstrucción de imágenes tanto de virus enteros como de complejos entre virus y ligandos (receptores, anticuerpos) con procesamiento de muestras nativas a muy bajas temperaturas -criomicroscopía electrónica- están proporcionando nueva información sobre relaciones estructura-función y aclarando en gran medida datos obtenidos con estudios genéticos.

Eladio Viñuela, a cuya memoria se dedica este volumen, tuvo la visión de que el desarrollo de la Virología requería una confluencia de abordajes experimentales complementarios, apoyada en técnicas distintas. El entendimiento profundo de un virus, en cualquier faceta de su ciclo de infección, no puede prescindir ni de la genética ni de la biología estructural, ni de la inmunología, ni de la evolución, ni de la enzimología, entre otras disciplinas relacionadas. El relato del progreso de la Virología a lo largo de la segunda mitad del siglo XX es una confirmación de la visión de Eladio Viñuela sobre la interdisciplinaridad de la Virología.

\section{Perspectivas de la Virología para el siglo XXI}

El relato histórico de párrafos anteriores ha subrayado los desarrollos metodológicos que han permitido un conocimiento detallado de los virus, 
sus mecanismos de replicación y las interacciones con sus hospedadores. ¿Qué conclusiones generales pueden derivarse de los estudios de la Virología empleando las nuevas herramientas del manejo de DNA recombinante ? A nuestro entender hay dos palabras clave que podrían considerarse definitorias: complejidad y diversidad. Es difícil en Virología establecer generalizaciones tanto respecto a la estructura como al comportamiento de los virus. Cada grupo de virus aparece como un universo único y fascinante merecedor de estudio. En los siguientes párrafos aventuramos, aún a riesgo de equivocarnos, algunos de los desafíos y líneas de investigación que deberían caracterizar a la Virología en las próximas décadas y cuál puede ser el papel de los grupos españoles en tales desafíos.

Los virus deberán seguir siendo sistemas modelo para elucidar mecanismos de replicación de DNA y su expresión en RNA y proteínas. Dada su simplicidad y facilidad de manejo, en especial la de los virus bacterianos, se seguirán utilizando para descifrar mecanismos básicos, tanto desde el punto de vista del conocimiento molecular de la compleja maquinaria replicativa como de los mecanismos que controlan la expresión de los genes. Todo ello, sin duda, será extrapolable a otros sistemas más complejos.

El empleo de virus para transferencias de genes heterólogos, en particular con fines de terapia génica, requerirá investigaciones básicas encaminadas a alcanzar una mayor especificidad de transferencia a células diferenciadas específicas y a dianas preseleccionadas del DNA de la célula receptora. Ello requerirá un mejor conocimiento de los receptores y correceptores presentes en cada tipo de célula diferenciada y de sus afinidades por distintos variantes víricos. Asimismo, un esfuerzo considerable deberá dirigirse a evitar la respuesta inmune frente a los propios vectores virales. Varios aspectos de seguridad en la manipulación genética de organismos enteros también quedan condicionados a dichas mejoras de especificidad. Los aspectos éticos de estas manipulaciones, principalmente cuando repercutan en alteraciones de la línea germinal humana, serán probablemente objeto de creciente debate en nuestra sociedad. El desarrollo de nuevos vectores virales para transferencias génicas está llamado a ser un capítulo importante de la Virología del siglo XXI.

Respecto al propio conocimiento de los virus y de sus ciclos infectivos, quedan multitud de tareas a completar, difíciles de enumerar por lo extenso de su contenido. Cabe destacar que se conocen de modo muy rudimentario procesos tan esenciales como son la penetración de partículas virales a través de la membrana celular, las bases moleculares 
del desensamblaje de los viriones para liberar su material genético en el interior de la célula, los mecanismos que regulan las cantidades de distintas proteínas víricas para que se de la estequiometría adecuada en cada etapa del ciclo replicativo, el proceso de ensamblaje de las partículas con reconocimientos específicos entre ácidos nucléicos y proteínas y el mecanismo de salida de las partículas infecciosas al exterior de la célula. Al igual que ha ocurrido históricamente, la elucidación del detalle molecular de las distintas etapas enumeradas aquí, puede tener una aplicación al mejor conocimiento de procesos celulares basados también en interacciones entre proteínas y entre ácidos nucleicos y proteínas.

El estudio de las distintas etapas de la replicación de virus patógenos -notablemente el virus de la inmunodeficiencia humana y retrovirus relacionados, el virus de la hepatitis $\mathrm{C}$ y otros posibles virus hepáticos patógenos cuya existencia se sospecha, así como nuevos virus emergentes como arenavirus y hantavirus - podrían definir nuevas dianas terapéuticas para el diseño de inhibidores antivirales. A pesar de ingentes esfuerzos por parte de la industria farmacéutica, existe un número muy limitado de agentes antivirales eficaces y uno de los desafíos de la Virología es traducir en aplicaciones prácticas el bagaje de conocimientos básicos acumulado hasta ahora. El diseño de nuevos agentes antivíricos constituye un ejemplo de lo importante de mantener una estrecha coordinación entre la investigación básica y la investigación aplicada.

El examen de las vacunas antivirales que se emplean en la actualidad revela que tan sólo unas pocas se han basado en los nuevos métodos de la ingeniería genética. Una de las excepciones más notables es la vacuna contra el virus de la hepatitis $B$, cuya administración no ha redundado en un control de la infección viral y de sus secuelas tan efectivo como podía anticiparse. Probablemente ello se deba a la falta de cobertura de la vacuna, asociada a los conflictos socioeconómicos que azotan buena parte del planeta, haciendo inaccesibles medidas preventivas y terapéuticas. Claramente el mapa de prevalencia de enfermedades infecciosas solapa con el mapa del subdesarrollo, y los problemas derivados de la pobreza en el mundo serán un impedimento para la aplicación práctica de los conocimientos de la Virología y de la Medicina en general.

Para numerosas enfermedades víricas tan importantes como son la hepatitis asociada al virus de la hepatitis C o el SIDA no existe ningún tipo de vacuna eficaz. Se dan varias circunstancias para explicar el escaso progreso en el diseño de vacunas para prevenir estas im- 
portantes enfermedades. Una es de tipo económico, por las pocas perspectivas de rentabilidad percibidas por la industria farmaceútica, incluso en el caso de que las vacunas mostraran buena eficacia. Otra circunstancia, relacionada con la anterior, es la gran diversidad genética $\mathrm{y}$ antigénica de las poblaciones virales que circulan en el mundo, y que hará necesario en muchos casos preparar una vacuna distinta para cada zona geográfica en donde se dé la enfermedad. Además, la heterogeneidad de los aislados virales (heterogeneidad incluso dentro de la población que replica en un individuo infectado) hace que sea necesario que la vacuna incluya multiples determinantes antigénicos capaces de estimular de modo efectivo tanto la rama humoral (producción de anticuerpos) como la rama celular (inducción de células $\mathrm{T}$ citotóxicas y células $\mathrm{T}$ cooperadoras con los linfocitos productores de anticuerpos) del sistema inmunitario. El carácter multivalente de las vacunas antivirales es necesario para disminuir las probabilidades de selección de virus que puedan escapar a la respuesta inmune inducida. Hasta 1994, el 90\% del esfuerzo en el diseño de vacunas para la prevención del SIDA se basaba en síntesis de péptidos que reproducían un sitio antigénico situado en una proteína de la superficie del virus, precisamente la estrategia más inadecuada para tratar de producir una vacuna eficaz frente a un virus tan variable como es el de la inmunodeficiencia humana. Afortunadamente, se está aceptando cada vez de modo más generalizado que las vacunas más prometedoras son aquellas consistentes en virus vivos atenuados o inactivados, independientemente de consideraciones de seguridad que indudablemente deben ser también abordadas. Es muy probable que el desarrollo de nuevas vacunas sea un campo de gran actividad en la Virología del siglo XXI.

Conceptos paralelos a los delineados para el diseño de vacunas son aplicables al empleo de inhibidores antivirales. Es necesaria la aplicación de varios inhibidores simultáneamente - lo que se conoce como terapia de combinación- para disminuir la probabilidad de selección de virus capaces de escapar a las acciones de inhibidores. El empleo de un solo inhibidor antirretroviral para controlar el virus de la inmunodeficiencia humana cuando se dispuso de los primeros inhibidores de este virus representó un experimento a gran escala que demostró la selección sistemática de virus resistentes a cada uno de los inhibidores administrados de forma individual. En cambio, mediante terapia de combinación con tres o más inhibidores - conocida como terapia altamente agresiva - que ha sido implementada en los últimos años, se ha reducido grandemente la replicación viral y se ha alargado 
espectacularmente la esperanza de vida de personas infectadas por el virus de la inmunodeficiencia humana. La búsqueda de nuevos inhibidores eficaces y con menos efectos secundarios que los producidos por los inhibidores disponibles actualmente, constituye un importante desafío para la Virología, no solamente para el control del SIDA sino también de numerosas enfermedades emergentes y reemergentes que tienen una etiología viral.

El mundo biológico, tanto el celular como el vírico, se halla en constante evolución. Las dificultades para el control de enfermedades víricas apuntadas en párrafos anteriores, tienen su raíz en parte en este elevado dinamismo genético de las poblaciones de virus que replican en los organismos infectados. Para virus RNA las tasas de error durante la replicación alcanzan valores promedio de una a dos mutaciones introducidas por cada genoma copiado durante la replicación. Tanto estudios teóricos como observaciones experimentales convergen en indicar que estas tasas de error se hallan muy cercanas a las máximas tolerables para el mantenimiento de la información genética del virus. Por ello, en los últimos años ha surgido interés en una nueva estrategia antiviral consistente en la aplicación de drogas que en vez de inhibir la replicación viral, disminuyan la fidelidad de copia hasta el punto de que el virus perdiera su identidad genética y su infectividad. Esta transición, denominada entrada del virus en catástrofe de error, será probablemente objeto de exploración en los próximos años ${ }^{31}$.

Se han descrito unas cuarenta nuevas enfermedades víricas emergentes (desconocidas hasta hoy día) o reemergentes (nuevas para una cierta área geográfica), que incluye nuevas enfermedades asociadas a agentes no convencionales (priones). El SIDA no es un caso único y los expertos predicen que un conjunto de factores socioeconómicos (desnutrición, conflictos bélicos que obligan a migraciones, grandes aglomeraciones urbanas, etc.) y ambientales (el cambio climático, construcción de pantanos que proporcionan grandes superficies de agua en las que proliferan larvas de insectos transmisores de virus, etc.) hará inevitable la aparición de nuevas enfermedades víricas en el futuro. Ello representa un importante desafío para la Virología tanto en aspectos básicos para entender los mecanismos de replicación de los nuevos virus como para habilitar métodos de diagnóstico, prevención y terapia.

No solamente las poblaciones víricas son muchísimo más complejas y dinámicas de lo sospechado tan solo hace dos décadas, sino que las interacciones virus-célula muestran una complejidad elevadísima. La célula responde a la infección viral mediante múltiples cambios en los niveles de expresión de numerosos RNAs y proteínas. Nuevas téc- 


\section{Una perspectiva sobre la situación actual de la Virología}

nicas analíticas basadas en hibridaciones selectivas a oligonucleótidos fluorescentes y métodos informatizados de detección, empiezan a entrar en escena. En particular, detecciones basadas en microchips (o «microarrays») de DNA podrán proporcionar tanto una visión global de las perturbaciones de expresión de genes celulares como una descripción más detallada de la composición genética (distinción entre genomas mayoritarios y minoritarios) de las poblaciones virales ${ }^{32}$. Creemos que la aplicación de nuevas técnicas físicas de análisis, apoyadas en el desarrollo de la informática, también contribuirá al desarrollo de la Virología en el siglo XXI. Un número considerable de virólogos españoles especialistas tanto en aspectos básicos como aplicados, relacionados con virus de bacterias, virus animales, virus de plantas y replicones subvirales, han alcanzado reconocimiento a nivel internacional, y sin duda contribuirán a resolver los múltiples desafíos que se plantean en Virología.

\section{Notas}

1. Loeffler, F. y Frosch, P. (1898). Berichte der Komission zur Erforschung der Maul-und Klauenseuche bei dem Institut für Infektionskrankheiten in Berlin. Zentralblatt für Bacteriologie, Parasitenkunde und Infektionskrankheiten. Parte I, Vol. 23, págs. 371-391.

2. Beijerinck, M.W. (1899). Ueber ein Contagium vivum fluidum als Ursache der Fleckenkrankheit der Tabaksblätter. Centralblatt für Bacteriologie und Parasitenkunde Parte II, Vol. 5, págs. 27-33.

3. Resúmenes de la historia de la Virología pueden hallarse en algunos libros de texto clásicos (Luria, S.E., Darnell, Jr., J.E., Baltimore, D. y Campbell, A. General Virology, $3^{\text {a }}$ edición, John Wiley and Sons, 1978; FraenKel-Conrat, M. y Kimbal, P.C. Virology, Prentice-Hall, Inc. 1982) y textos recientes (Fields, N. et al., editores, Fields Virology, $3^{\text {a }}$ edición, Lippincott-Raven, 1996; Granoff, A. y Webster, R.G., editores, Encyclopedia of Virology, $2^{a}$ edición, Academic Press, 1999).

4. Stanley, W.M. (1935). Isolation of crystalline protein possessing the properties of the tobacco-mosaic virus. Science 81, 644-645.

5. Bawden, F.C. y Pirie, N.W. (1937). The isolation and some properties of liquid crystalline substances from solanaceous plants infected with three strains of tobacco mosaic virus. Proc.Roy.Soc. 123, 274-320.

6. d'Herelle, F.H. (1917). $\subseteq$ ur un microbe invisible antagoniste des bacilles dysentériques. C.R. Hebd.Seanc.Acad.Sci. Paris 165, 373-390.

7. Un interesante relato de lo que representó la escuela de Max Delbrück y sus asociados para el desarrollo de la Biología Molecular y de la Virología es el de: Cairns, J., Stent, G.S. y Watson, J.D. eds. Phage and the Origins of Molecular Biology, Cold Spring Harbor Laboratory Press, 1992 (versión expandida de la original de 1966).

8. Hershey, A.D. y Chase, M. (1952). Independent functions of viral protein and nucleic acid in growth of bacteriophage. J.Gen.Physiol. 36, 39-56. 
9. Loeb, T. y Zinder, N.D. (1961). A bacteriophage containing RNA. Proc.Natl.Acad.Sci.USA 47, 282-286.

10. Spiegelman, S., Haruna, I., Holland, I.B., Beaudreau, G. y Mills, D. (1965). The synthesis of self-propagating and infectious nucleic acid with a purified enzyme. Proc.Natl.Acad.Sci.USA 54, 919-923.

11. Feix, G., Slor, H. y Weissmann, C. (1967). Replication of viral RNA. XIII. The early product of phage RNA synthesis in vitro. Proc.Natl.Acad.Sci.USA 57, 14011408.

12. Viñuela, E., Algranati, M., I. y Ochoa, S. (1967). Synthesis of virus-specific proteins in $E$. coli infected with the RNA of bacteriophage MS2. Eur. J. Biochem. 1, 3-11; M. Salas, M.B. Hille, J.A. Last, A.J. Wahba y S. Ochoa (1967). Translation of the genetic message. II. Effect of initiation factors on the binding of formyl-methionyltRNA to ribosomes. Proc. Natl. Acad. Sci. USA, 57, 387-394. Vinuela, E., Salas, M. y Ochoa, S. (1967). Translation of the genetic message. III. Formylmethionine as initiator of proteins programed by polycistronic messenger RNA. Proc. Natl. Acad. Sci. USA 57, 720-734.

13. Shapiro, A.L., Viñuela, E. y Maizel, H.V. (1967). Molecular weight estimation of polypeptide chains by electrophoresis in SDS-polyacrylamide gels. Biochem. Biophys. Res. Commun. 28, 815-820.

14. Méndez, E., Ramírez, G., Salas, M. y Viñuela, E. (1971). Structural proteins of bacteriophage $\varnothing 29$. Virology, 45, 567-576.; Jiménez, F., Camacho, A., de la Torre, J., Viñuela, E. y Salas, M. (1977). Assembly of Bacillus subtilis phage ø29. II. Mutants in the cistrons coding for the nonstructural proteins. Eur. J. Biochem., 73, 57-72; Ortín, J., Viñuela, E., Salas, M. y Vásquez, C.(1971). DNA-protein complex in circular DNA from phage ø29. Nature New Biol., 234, 275-277; Salas, M., Mellado, R.P., Viñuela E. y Sogo, J.M. (1978). Characterization of a protein covalently linked to the 5' termini of the DNA of Bacillus subtilis phage ø29. J. Mol. Biol., 119, 269-291; Peñalva, M.A. y Salas, M. (1982). Initiation of phage $\emptyset 29$ DNA replication in vitro: Formation of a covalent complex between the terminal protein, p3, and 5'dAMP. Proc. Natl. Acad. Sci. USA, 79, 5522-5526. Salas, M. (1991). Protein-priming of DNA replication. Annu. Rev. Biochem., 60, 39-71.

15. Relatos interesantes de los orígenes de la biología molecular y de la virología en España, expuestos por varios alumnos y colaboradores de Eladio Viñuela y Margarita Salas en el Centro de Investigaciones Biológicas y en el Centro de Biología Molecular "Severo Ochoa" se hallan recopilados en el Libro-Homenaje a Eladio Viñuela: Fago $\emptyset 29$ y los orígenes de la Biología Molecular en España, Toral Impresores, Madrid 1998.

16. Flavell, R.A., Sabo, D.L., Bandle, E.F. y Weissmann, C. (1974) Site-directed mutagenesis: Generation of an extracistronic mutation in bacteriophage $Q \beta$ RNA. J.Mol.Biol. 89, 255-272.

17. Batschelet, E., Domingo, E. y Weissmann, C. (1976). The proportion of revertant and mutant phage in a growing population, as a function of mutation and growth rate. Gene 11, 27-32; Domingo, E., Sabo, D., Taniguchi, T. y Weissmann, C. (1978). Nucleotide sequence heterogeneity of an RNA phage population. Cell 13, 735-744.

18. Fiers, W., Contreras, R., Duerinck, F., Hageman, G., Iserentant, D., Merregaert, J., Min Jou, W., Molemans, F., Raeymaekers, A., Van den Berghe, A., Volckaert, G. y Ysebaert, M. (1976). Complete nucleotide sequence of bacteriophage MS2 RNA: primary and secondary structure of the replicase gene. Nature 260, 500-506. 


\section{Una perspectiva sobre la situación actual de la Virología}

19. Baltimore, D. (1970). Viral RNA-dependent RNA polymerase. Nature 226, 1209-1211; Temin, H.M. y Mizutani, S. (1970). RNA-dependent DNA polymerase in virions of Rous sarcoma virus. Nature 226, 1211-1213; como recopilación de trabajos sobre la hipótesis proviral y sus implicaciones en Virología y Oncología, véase Cooper, G.M., Greenberg Temin, R. y Sugden, B., editores, The DNA provirus. Howard Temin's scientific legacy, ASM Press., 1995.

20. Existen numerosos manuales que describen los métodos de manipulación de DNA in vitro. El más clásico, todavía empleado como referencia en los laboratorios de investigaciçon es el de Sambrook, J., Fritsch, E.F. y Maniatis, T. (1989). Molecular Cloning. A Laboratory Manual. Cold Spring Harbor Laboratory Press. En España Marta Izquierdo ha publicado una excelente introducción al tema: Ingeniería Genética, Ediciones Pirámide S.A., 1993.

21. M.R. Inciarte, J.M. Lázaro, M. Salas y E. Viñuela (1976). Physical map of bacteriophage $\emptyset 29$. Virology, 74, 314-323.

22. Berg, P. (1981). Dissections and reconstructions of genes and chromosomes. Science 213, 296-303.

23. Gilbert, W. (1981). DNA sequencing and gene structure. Science 214, 1305-1312; Sanger, F. (1981). Determination of nucleotide sequences in DNA. Science 214, 12051210.

24. Escarmís, C. y Salas, M. (1981). Nucleotide sequences at the termini of the DNA of Bacillus subtilis phage ø29. Proc.Natl.Acad.Sci.USA 78, 1446-1450.

25. Yáñez, R.J., Rodríguez, J.M., Nogal, M.L., Yuste, L., Enríquez, C., Rodríguez, J.F. y Viñuela, E. (1995). Analysis of the complete nucleotide sequence of African swine fever virus. Virology, 208, 249-278. Una revisión reciente del trabajo del grupo de Eladio Viñuela sobre el virus de la peste porcina africana puede hallarse en: Salas, J., Salas, M.L., y Viñuela, E., En: Origin and Evolution of Viruses, Domingo, E., Webster, R.G. y Holland, J.J., editores. Págs. 467-480. Academic press, San Diego 1999. Este volumen fue dedicado a la memoria de Eladio Viñuela por los editores.

26. Shortle, D. y Nathans, D. (1978). Local mutagenesis: a method for generating viral mutants with base substitutions in preselected regions of the viral genome. Proc.Natl.Acad.Sci.USA. 75, 2170-2174.

27. Taniguchi, T., Palmieri, M. y Weissmann, C. (1978). Qß DNA-containing hybrid plasmids give rise to $\mathrm{Q} \beta$ phage formation in the bacterial host. Nature 274, 223-228; Racaniello, V.R. y Baltimore, D. (1981). Cloned poliovirus complementary DNA is infectious in mammalian cells. Science 214, 916-919. Actualmente, la mayoría de virus RNA pueden ser manipulados a nivel de copias de DNA y generar virus infeccioso.

28. El primer trabajo en el que se describió el PCR fue: Saiki, R.K., Scharf, S., Faloona, F., Mullis, K.B., Horn, G.T., Erlich, H. y Arnheim, N. (1985). Enzymatic amplification of $\beta$-globin genomic sequences and restriction site analysis for diagnosis of sickle cell anemia. Science 230, 1350-1354. Varias monografías muestran la amplia influencia de esta nueva técnica en todos los campos de la biología; como ejemplos: PCR Technology, H.A. Erlich, ed., Stockton Press, 1989 y PCR Protocols for Emerging Infectious Diseases, D.H. Persing, ed. ASM Press, 1996, una monografía particularmente relevante para uno de los principales desafíos de la virología actual: las enfermedades víricas emergentes.

29. Berget, S.M., Moore, C. y Sharp, P.A. (1977).Spliced segments at the 5 'terminus of adenovirus 2 late mRNA. Proc.Natl.Acad.Sci.USA 74, 3171-3175. Como resúmenes históricos e implicaciones biológicas de la discontinuidad de genes, ver: Crick, F. (1979). 
Split genes and RNA splicing. Science 204, 264-271; Chambon, P. (1981). Split genes. Scientific American 244, 60-71; Perry, R.P. (1981). RNA processing comes of age. J.Cell.Biol. 91, 28s-38s.

30. Köhler, G y Milstein, C. (1975). Continuous cultures of fused cells secreting antibody of predefined specificity. Nature 256, 495-497. Entre muchas aplicaciones de los anticuerpos monoclonales a la Virología cabe destacar los trabajos clásicos con el virus de la gripe: Gerhard, W., Yewdell, J., Frankel, M., y Webster, R.G. (1981). Antigenic structure of influenza virus hemagglutinin defined by hybridoma antibodies. Nature 290, 713-717.

31. Domingo, E. (2000). Viruses at the edge of adaptation. Virology 270, 251-253 (y referencias allí indicadas).

32. Kanehisa, M. Post-genome Informatics. Oxford University Press, 2000; Leslie, R.A. y Robertson, M.A., (editores), Differential Display. Oxford University Press, 2000. 